SABINA GIERGIEL

Uniwersytet Opolski

e-mail: sgiergiel@uni.opole.pl

\title{
Stłumiona narracja. Igora Marojevicia opowieść o naddunajskich Szwabach
}

\author{
Abstract \\ Suppressed Narration: Igor Marojević's Story about the Danube Swabians
}

On the South Slavic territories, the end of the World War II came with the victory of communism. As a result, post-war decades in Yugoslavia were subordinated to the partisan ethos founded on the myth of the struggle with fascism. Directly after the war, this struggle assumed disposing of the so-called domestic enemies amongst whom there were also the Germans living in the Serbian Vojvodina from the $18^{\text {th }}$ century. In the post-war Serbia, diversified repressions (displacements, forcible work, camp experience, confiscation of things) were aimed at the German people, predominantly civilians. These repressions constituted the taboo in the Yugoslavian national discourse, with this situation lasting for a number of decades.

In his book Majčina ruka, Igor Marojević, the Serbian prose-writer of the middle generation (born 1968), undertakes the issue of the Vojvodina Germans' post-war fortunes. Consequently, he inscribes his literary activity into the current discussions on the ignored, erased and dissembled events from the history of Yugoslavia. Recovering the memory about them, he questions the black-and-white picture of the world built on the partisans vs. the fascists opposition, which was created after the war.

Keywords: Danube Swabians, domestic enemies, trauma, suppression, repressions.

Słowa kluczowe: naddunajskie Szwaby, wrogowie wewnętrzni, trauma, stłumienie, represje.

„To nie jest powieść historyczna ani o historii, lecz powieść o dorastaniu pewnego chłopca, na które nagle pada cień historii" - takimi słowami rozpoczyna się utwór Igora Marojevicia Majčina ruka [Matczyna ręka] ${ }^{1}$. Powieść ta posłuży jako przykład konceptualizacji stosunkowo nowej tematyki w literaturze serb-

1 I. Marojević, Majčina ruka, Beograd 2011. Wszystkie przekłady, o ile nie zaznaczono inaczej, pochodzą od autorki tekstu. 
skiej, a mianowicie problematyki wysiedleń i represji powojennych, jakim zostali poddani tamtejsi Niemcy ${ }^{2}$. Biorąc pod uwagę fakt, że tematyka związana z obecnością i „zniknięciem” z terenów Serbii mniejszości niemieckiej nie jest zapewne znana polskiemu czytelnikowi, tekst właściwy został uzupełniony o (umieszczone w przypisach) informacje o charakterze historycznym.

Ważną inspiracją w niniejszym artykule są rozważania poczynione przez Przemysława Czaplińskiego w tekście Języki niezależności. Autor wychodzi w nim od pytania zadanego przez Gayatri Chakravorty Spivak: „Czy podporządkowani inni mogą przemówić?"’3, a następnie precyzuje, że jego celem jest badanie tych głosów, które „mają reprezentować ludzi postzależnych, czyli tych, którzy postrzegają ograniczenia swojej wolności jako skutki przemiany ustrojowej”". Takimi właśnie ludźmi są dla mnie fikcyjni bohaterowie - mieszkający w Wojwodinie przedstawiciele narodu niemieckiego, których głosy prezentuje książka Marojevicia. Powieść bowiem podejmuje marginalizowane przez oficjalny dyskurs wydarzenia z powojennej historii Serbii, a mianowicie kwestie samosądów, wysiedleń i represji, jakie tuż po drugiej wojnie światowej dotknęły przedstawicieli mniejszości niemieckiej. Niemcy (w tradycji serbskiej określani mianem Szwabów), którzy od XVIII wieku osiedlali się na terenach dzisiejszej Wojwodiny, zostali wówczas automatycznie zaliczeni do nieprzyjaciół ${ }^{6}$. Taka polaryzacja określiła wzajemne stosunki przedstawicieli obu narodów w Serbii i sprawiła, że niepra-

2 Należy podkreślić, że temat obecności Niemców na terenach państw bloku wschodniego, a zwłaszcza ich powojennych losów, obecny jest w narodowych literaturach między innymi: Serbii, Chorwacji, Czech, Słowacji i Rumunii. W kontekście literatury chorwackiej pisała o tym Magdalena Dyras, Rekonstrukcje tożsamości ,,naddunajskich Szwabów” wobec wielojęzyczności kulturowej [w:] Konstrukcje i destrukcje tożsamości, t. 2: Tożsamość wobec wielojęzyczności, red. E. Golachowska, A. Zielińska, Warszawa 2012, s. 167-178. O czeskiej literaturze podejmującej tę problematykę pisze Anna Gawarecka, Dialog i milczenie w czeskiej prozie poświęconej tematyce wysiedlania Niemców [w:] Przemilczenia w relacjach międzykulturowych, red. J. Goszczyńska, G. Szwat-Gyłybowa, Warszawa 2008, s. 195-215. W literaturze serbskiej na szerszą skalę problematyka ta pojawia się po $2000 \mathrm{r}$. Do pisarzy ją podejmujących należą m.in: Dragi Bugarčić, Nenad Novak Stefanović, Nemanja Rotar, Ivan Ivaniji.

${ }^{3}$ W tej formie w języku polskim funkcjonuje przywoływany przez Czaplińskiego esej: G.Ch. Spivak, Czy podporzadkowani inni moga przemówić, tłum. E. Majewska, „Krytyka Polityczna” 2011, nr 24-25, s. 196-239. Czapliński zaś tytułowe pytanie tłumaczy nieco inaczej, a mianowicie: „Czy klasy podrzędne potrafią mówić?”. P. Czapliński, Język niezależności. Jak jest artykułowana w literaturze niepodległość odzyskana przez Polskę w roku 1989? [w:] Kultura po przejściach, osoby z przesztościa. Polski dyskurs postzależnościowy - konteksty i perspektywy badawcze, red. R. Nycz, Kraków 2011, s. 40.

4 Ibid.

5 Jak pisze M. Dyras: „Mianem Niemców - Szwabów, określano [...] wszystkich przybyszów posługujących się językiem niemieckim, niezależnie od pochodzenia, oni zaś sami nie mieli wyrazistego poczucia przynależności narodowej”. M. Dyras, op. cit., s. 168.

6 Niemiecka kolonizacja miała ekonomiczny charakter, jej celem było polepszenie sytuacji terenów, które przez 150 lat wchodziły w skład tureckiego imperium. Część dzisiejszej Serbii i Chorwacji od 1699 r. (tj. od pokoju w Sremskich Karłowicach, kończącego wojnę Świętej Ligi z Turkami) stała się celem wędrówek wielu grup narodowościowych (przede wszystkim Niemców, ale i Węgrów, Czechów oraz Słowaków). Monarchia habsburska pragnęła bowiem jak najlepiej wykorzystać potencjał tych urodzajnych ziem, zasiedlając opuszczone przez Turków tereny swymi poddanymi. Zob. Z. Janjetović, Srbi i Nemci u Vojvodini: negativna iskustva zajedničkog života, http://www.drustvosns.org/ 
wości, jakie dotknęły Niemców, przez dziesięciolecia konsekwentnie przemilczano. Tabu związane z tymi wydarzeniami (obecne w obrębie tzw. pamięci oficjalnej, jak i - w znacznej mierze - również w rodzinnej ${ }^{7}$ ) zostało przełamane dopiero na początku lat $90 .{ }^{8}$ Marojević w swym tekście tworzy fikcjonalny przekaz o tej właśnie „zakazanej narracji”.

Procesy marginalizacji cierpień mniejszości niemieckiej mają swe bezpośrednie korzenie w historii, a dokładnie w fakcie okupacji terytorium Jugosławii, i szerzej: w niemieckiej winie $z$ lat drugiej wojny światowej ${ }^{10}$. Przez całe dziesięciolecia głosy świadczące o cierpieniach niemieckich cywilów były nieobecne w oficjalnym dyskursie, a ich doświadczenie ,nie zasługiwało” na to, by zostać wypowiedziane ${ }^{11}$. Pamięć o tych wydarzeniach została zachowana w dyskursie niemieckim (największa liczba świadectw powstała w Niemczech w latach 1953-1962), natomiast w serbskiej świadomości fakty te praktycznie nie istniały aż do 1997 roku, kiedy to w Belgradzie ukazała się książka Jedan svet na Dunavu - Razgovori $i$ komentari ${ }^{12}$. Zróżnicowana dystrybucja prawa do żałoby sprawiła, że Niemcom odebrano prawo głosu na całe dziesięciolecia, sytuując ich narracje po stronie opowieści kolaborantów, a wszystkim przedstawicielom narodu przypisując zbiorową winę.

nemacka\%20manjina/janjetovic/Z.\%20Janjetovic,\%20Srbi\%20i\%20Nemci\%20u\%20Vojvodini,\%20 negativna\%20iskustva\%20zajednickog\%20zivota.pdf (dostęp: 24.05.2016).

7 W wielu tekstach poświęconych losowi Niemców można przeczytać, że doświadczenie obozowe (w przypadku kobiet niejednokrotnie połączone z wykorzystywaniem seksualnym) najczęściej nie było przekazywane kolejnym pokoleniom w rodzinie. Zob. N. Horozović, Istraživanje: tišina od 60 godina, http://nenasilje.org/2010/istrazivanje-tisina-od-60-godina/ (dostęp: 29.07.2016).

8 Marijana Stojčić łączy ten fakt $\mathrm{z}$ działaniami mającymi na celu wyrażenie sprzeciwu wobec tzw. homogenizacji narodu. Powstają wówczas zręby serbskiego społeczeństwa obywatelskiego, rozwijają się organizacje pozarządowe zajmujące się prawami człowieka i podejmujące tematy dotąd spychane na margines. Początek lat 90 . to również okres, w którym w Wojwodinie zaczynają powstawać niemieckie stowarzyszenia, aktywnie włączające się w działalność mającą na celu przypomnienie o niemieckiej historii tego regionu. M. Stojčić, Recepcija stradanja Nemaca i Nemica iz istočnoevropskih oblasti nakon drugog svetskog rata u Nemačkoj i Podunavskih Nemaca/ica u Srbiji/Jugoslaviji, s. 26-33 (w druku). W tym miejscu dziękuję autorce artykułu i Katarzynie Taczyńskiej za umożliwienie mi zapoznania się z tym tekstem. Po zmianie władzy w 2000 r. (kiedy to po masowych protestach i oskarżeniach o sfałszowanie wyborów Slobodan Milošević oddał ją Vojislavovi Koštunicy) Serbia zaczyna aspirować do członkostwa w UE, w wyniku czego zmuszona jest zredefiniować miejsce, jakie zajmują w niej mniejszości narodowe. Również z tym faktem można łączyć coraz wyraźniejszą obecność w kulturze tematów związanych z traumą serbskich Niemców.

9 Termin ,zakazana narracja” pochodzi od Davida Carrola. D. Carrol, Reguły gry, przeł. G. Dziamski [w:] Postmodernizm w perspektywie filozoficzno-kulturowej, red. A. Zeidler-Janiszewska, Warszawa 1991, s. 57.

${ }_{10}$ Podział Jugosławii w czasie drugiej wojny światowej spowodował zmianę wzajemnych relacji pomiędzy oboma narodami. Na terytorium Bački i Baranji (przyłączonych do Węgier) przedstawiciele narodów niemieckiego i serbskiego traktowani byli jako mniejszości narodowe. Terytorium Sremu i Banatu weszło w skład NDH. Na terenie Sremu Niemcy walczyli z Chorwatami o władzę nad regionem, w Banacie zaś to Niemcy byli nosicielami władzy i wykonawcami poleceń, jakie docierały z okupowanego Belgradu. Zob. Z. Janjetović, op. cit.

${ }_{11}$ Zob. J. Butler, Ramy wojny. Kiedy życie godne jest opłakiwania?, przeł. A. Czarnecka, Warszawa 2011.

12 Jedan svet na Dunavu - Razgovori i komentari, red. N. Stefanović, Beograd 2007. 
Metodologiczne ramy interpretacji tekstu Marojevicia wyznacza teoria traumy oraz badania postzależnościowe. Pojęcia oraz narzędzia powiązane $\mathrm{z}$ analizą dyskursów postzależnościowych posłużą mi do nakreślenia pozycji, z jakiej się mówi. Nie chodzi mi jednak w niniejszym tekście o rozważania nad całą grupą podporządkowaną, ale raczej o namysł nad jednostkowym głosem (głosem fikcyjnym Niemki - bohaterki powieści), należącym do reprezentanta społeczności, która w określonych warunkach (koniec lat 70.) może korzystać jedynie z ograniczonej wolności. Głos ten zostaje zapośredniczony przez dwie instancje: fikcyjnego bohatera i autora empirycznego.

Główną postacią utworu Marojevicia jest chłopiec (Serb), mający około 15 lat. Mieszka on w czarnogórskim Peraście, jednak po trzęsieniu ziemi, jakie w kwietniu 1979 roku dotknęło Bokę Kotorską, jego matka decyduje, by na czas remontu domu przeniósł się do Wojwodiny (a dokładnie do Vrbasu - miejsca o ,przerwanej/pękniętej historii"'13), gdzie mieszka jej najstarsza siostra - niezamężna Bonja. Kilka miesięcy spędzonych w Vrbasie upływa chłopcu na zabieganiu o wdzięki kobiet (sióstr Herty i znacznie od niej starszej Sonji Schlösser). Jest to również czas, w którym poznaje on historię kamienicy zamieszkanej przez jego rodzinę i pośrednio dowiaduje się o losie naddunajskich Niemców, jak również serbskich powojennych przesiedleńców z terenów pogranicza czarnogórsko-hercegowińskiego.

Co ciekawe, serbski prozaik w swym tekście konstruuje podwójną perspektywę, a mianowicie przekazuje głos podporządkowanych (Niemców), ale i serbskich kolonistów w Wojwodinie ${ }^{14}$, reprezentujących przecież także opowieść marginalizowaną, a jednocześnie nadrzędną wobec głosu Niemców. Dyskursem stłumionym jest bowiem również niewypowiedziane cierpienie przedstawicieli serbskiego narodu, którzy z terenów tzw. Starej Hercegowiny po wojnie zostali przesiedleni do Wojwodiny i tam zamieszkali w domach zarekwirowanych rodzinom niemieckim. Proces oswajania przestrzeni (w powieści mowa jest m.in. o zmianie nazw ulic ${ }^{15}$ ), powiązany $\mathrm{z}$ adaptacją do tego, co nowe (zmiana krajobrazu z górskiego na panońską równinę), dla wielu z nich nigdy się nie kończy (może dlatego niektórzy wybierają samobójstwo). Rodzina głównego bohatera doskonale radzi sobie $\mathrm{z}$ tymi procesami, jednak w poniemieckim domu pozostają

13 Termin ,przerwana/pęknięta historia” doskonale określa specyfikę miejsca akcji powieści, tj. Vrbasu, którego społeczność w przeszłości kilkakrotnie ulegała „wymianie”. Vrbas to zatem u Marojevicia przestrzeń ,niemożliwa”, a jednak realnie istniejąca, przestrzeń wielokrotnie naznaczona cierpieniem, wykluczeniem i podporządkowaniem.

14 Nowi osadnicy przybywają do Wojwodiny po przyjęciu ustawy o reformie agrarnej i kolonizacji z wielu regionów Jugosławii: z Bośni i Hercegowiny, Liki, Kordunu, Czarnogóry, Dalmacji, Sandżaku, Serbii, Macedonii, Słowenii i Kosowa. Masowe przesiedlenia trwały od końca 1945 do końca 1946 r., ale do Wojwodiny przybywano aż do 1948 r. Osadnicy trafili tam do 114 miejscowości, w których otrzymali nieco ponad 668000 ha ziemi. Dane te podaję za: N. Horozović, op. cit.

15 Zastąpienie „obcej” toponimii nazwami własnymi jest najbardziej podstawowym sposobem oswajania miejsca. Za pomocą języka dokonywany jest pierwszy etap kolonizacji. Mechanizmy te we wszystkich krajach, w których przetasowania ludności miały miejsce, są analogiczne. O czeskiej kolonizacji Sudetów po drugiej wojnie światowej A. Gawarecka pisze w ten sposób: „Eliminacja niemczyzny prowadzić ma nie tylko do uprawomocnienia obecności Czechów w regionie, lecz rozpoczyna również proces zapominania o jego historycznej przeszłości”. A. Gawarecka, op. cit., s. 207. 
znaki obcości, swoiste mikrokomunikaty świadczące o przeszłości tego miejsca. Jest to np. niemiecki napis na kominku, dla mieszkańców domu niewidzialny, przezroczysty, który intryguje jednak chłopca, uznającego go za coś egzotycznego, niepasującego do otoczenia. A zatem dom sam w sobie stanowi pewną zagadkę, nosi w sobie tajemnicę, zamkniętą w enigmatycznym palimpseście historii. Podobnie jak w polskiej powieści lat 90., u Marojevicia

miasto i miejsce zbudowane [...] zostało na fundamencie opowieści [do pewnego momentu niemożliwej do wypowiedzenia, odgórnie tłumionej - S.G.] o wykorzenieniu doświadczonym przez aktualnych mieszkańców. Spod tej dominującej i, wydawałoby się, ze wszech miar słusznej opowieści na temat sprawiedliwego przejęcia miejsca, przebija warstwa wcześniejsza, losów innego mieszkańca, innego języka, warstwa niepokojącej obcości ${ }^{16}$.

Można zatem powiedzieć, że Vrbas, najpierw zasiedlony przez Niemców, a następnie skolonizowany przez Serbów z pogranicza czarnogórsko-hercegowińskiego, jest miejscem wytrąconym z czasowej ciągłości, miejscem, do którego nie można bezwzględnie przynależeć ${ }^{17}$. W opowieści o rodzinnym mieście Marojevicia nieustannie zderzają się opozycyjne względem siebie narracje, uniemożliwiające - tak długo, dopóki wszystkie nie zostaną uznane za równie ważne - stworzenie jednej nadrzędnej opowieści o miejscu, z którym historia nie obeszła się łagodnie. Jest to bowiem przestrzeń, w obrębie której obecne są palimpsestowo nałożone i nieprzystające do siebie opowieści. W Vrbasie zderzają się wzajemnie sprzeczne fragmenty ,wielkiej” historii i wykluczające się wspomnienia jednostek. To nieznane i niepokojące oblicze miasta stopniowo odkrywa się przed bohaterem i odbija w niedomówieniach, zaprzeczeniach, zmianach tematu, towarzyszących jego śledztwu dotyczącemu pochodzenia sióstr Schlösser i historii domu, w którym mieszka.

Zakazy, opisy funkcjonowania społecznego tabu połączone z redukcją niewygodnego głosu pojawiają się w powieści na kilku poziomach. Z jednej strony mamy dyskurs dominujący, którego centrum znajduje się w obrębie przekazu aprobowanego i rozpowszechnianego przez władze komunistyczne. Z drugiej strony dyskursem podporządkowanym (bądź podporządkowanych) jest niewypowiedziana opowieść o represjach, jakim podlegały jednostki o niemieckim pochodzeniu. O tym, jak bardzo wówczas była to wiedza strzeżona, świadczy fakt, że w związku ze - jak mniema Urząd Bezpieczeństwa - zbytnią ciekawością chłopca (bohatera powieści) jego matka zostaje wezwana na przesłuchanie, a cała rodzina obawia się nieprzyjemności. Głosem tłumionym przez centrum są również pierwsze wspomnienia serbskich osadników, którzy sami będąc niejako kolonizowanymi, kolonizują innych (poprzez podkreślane wyrównywanie krzywd i lekceważenie podrzędnego wobec nich głosu, tj. doświadczenia Niemek - kole-

16 D. Kołodziejczyk, Odzyskiwanie miejsca: realizm magiczny w powieści postkolonialnej i polskiej powieści lat dziewięćdziesiątych XX wieku [w:] Nie)obecność. Pominięcia i przemilczenia w narracjach XX wieku, red. H. Gosk, B. Karwowska, Warszawa 2008, s. 148.

17 Nawiązuję tu raz jeszcze do rozważań i sformułowań Doroty Kołodziejczyk dotyczących powieści Stefana Chwina (Hanemann), Pawła Huellego (Weiser Dawidek) czy Olgi Tokarczuk (Dom dzienny, dom nocny). Zob. ibid. 
żanek bohatera). Ta wielostopniowa konstrukcja przewija się mniej lub bardziej wyraźnie przez całą powieść.

Niemiecka opowieść jest dość typowa: w 1944 roku w obawie przed partyzantami większość z nich pospiesznie opuszcza Wojwodinę; pozostali czekają, mając nadzieję, że unikną przeczuwanej przez część ich rodaków zemsty. Następnie do Vrbasu docierają Rosjanie, a zaraz po nich partyzanci ${ }^{18}$.

Zachowywali się całkiem przyzwoicie, chociaż niektóre dziewczęta próbowali napastować. [...] W gimnazjum w Nowym Vrbasie przybycie Rosjan [...] oraz poprzedzającą je ucieczkę lokalnych Szwabów nazywano wyzwoleniem... Wkrótce z Ratusza, z cmentarza i z cukrowni zaczęły dobiegać odgłosy wystrzałów. To partyzanci, którzy po Rosjanach weszli do Nowego i Starego Vrbasu, rozpoczęli likwidacje niektórych Niemców. Ponoć zabijali bez sądu zarówno tych, którzy walczyli w czasie wojny, jak i tych, którzy nie brali w niej udziału ${ }^{19}$.

Majątek rodzin, które pozostały w Serbii, uległ konfiskacie (na rzecz kolonistów) bądź też do ich mieszkań dokwaterowano komunistów ${ }^{20}$. Niemcy ponadto niejednokrotnie trafiali do obozów pracy przymusowej ${ }^{21}$. O tych wydarzeniach w Vrbasie z lat 70. się nie mówi, choć jest to powszechnie znana, aczkolwiek przemilczana, wiedza.

Główny bohater utworu w trakcie śledztwa, jakie prowadzi, natrafia na następujące dokumenty: zwolnienie z obozu pracy matki Sonji wraz z jej małoletnią córką oraz list pisany przez ojca Herty. To z listu dowiaduje się o warunkach panujących w obozie.

Marznę w głębokim śniegu w letnim ubraniu i płytkich butach, rozgrzewając się jedynie podczas pracy na polu fabryki jedwabiu; kiedy skończyły się prace polowe, nie mam się jak rozgrzać, tylko sześć godzin dziennie bez przerwy, tak jak pozostali, stoję w szeregu bez powodu; jem koniczynę i trawę, gdy jestem głodny po obiedzie składającym się z herbaty, kukurydzy, polenty, niesłonego kukurydzianego chleba i fasoli z delikatesami: pływającymi po niej owadami, który nam dają; prawie co dzień jestem bity, wszystkie kości mnie bolą i wypadają mi zęby; $[\ldots]$ jeśli już nie ma miejsca w fabryce, to śpię na zewnątrz; czasem usypiam przy dźwiękach nocnego napastowania; dotarło do mnie, że te biedne kobiety bardziej krzyczą po nim, niż w jego trakcie ${ }^{22}$.

18 Tuż przed wybuchem wojny w Jugosławii mieszkało około pół miliona Niemców. Pod koniec wojny było ich około 200 000. Po tym, jak w 1944 r. Armia Czerwona przekroczyła Dunaj, około 30000 jeńców i robotników przymusowych wysłano do Związku Radzieckiego. J. Mirnić, Nemci u Bačkoj u Drugom svetskom ratu, Novi Sad 1974, s. 332 i 327, za: M. Stojčić, op. cit., s. 23.

19 I. Marojević, op. cit., s. 92.

2021 listopada 1944 r. AVNOJ podjął decyzję, na mocy której konfiskata majątku objęła wszystkich Niemców (z wyjątkiem tych, którzy walczyli w szeregach partyzantów, pomagali ruchowi bądź pozostawali w mieszanych małżeństwach). S. Petrović Todosijević, Na putu. Repatrijacija dece pripadnika nemačke nacionalne manjine u Jugoslaviji posle Drugog svetskog rata (1948-1956), „Tokovi istorije" 2012, nr 3, s. 193. Zob. też T. Kuljić, Prevladanje prošlosti. Uzroci i pravci promene slike istorije krajem XX veka, Beograd 2002, s. 410-411.

21 Między 1944 a 1948 r. na terenie Wojwodiny funkcjonowało około 10 obozów. Na przełomie 1945 i 1946 r. znajdowało się w nich około 105000 Niemców. T. Kuljić, op. cit.; S. Petrović Todosijević, op. cit., s. 355.

22 I. Marojević, op. cit., s. 119. 
Potrzeba poznania prawdy o siostrach Schlösser i historii kamienicy, w której mieszka, prowadzi bohatera do miejskiej biblioteki, gdzie przegląda prasę z 1946 roku. Gazety z okresu przesiedleń wypełnione są propagandowymi hasłami, w których Serbowie to „nasi”, a domy niemieckich rodzin to „majątek faszystów"23. Marojević, nie kwestionując niemieckiej winy i posiłkując się ironią, wskazuje na propagandowy potencjał gazet z lat 40. Chłopiec w jednej z nich znajduje np. informację, że Niemcy zabili pewną liczbę Serbów.

Wyjaśnienie brzmiało mniej więcej tak, że oni wcale nie musieli zabijać, ale zbrodnie sprawiały im taką przyjemność, że zgłaszali się do różnego typu akcji, które przygotowywali Węgrzy. A iluż to mieszkańców Bački mogliby zabić, gdyby tylko przez cały czas byli tu u władzy i nie zabijali ot tak, dla czystej przyjemności? ${ }^{24}$

Wiktymologia uczy, że zaprzeczanie niewinności ofiar należy do fundamentalnych zabiegów sprawców przemocy, którzy w ten sposób próbują usprawiedliwić własną agresję ${ }^{25}$. Niejednokrotnie przez bohaterów powieści dokonywane jest swoiste zestawienie krzywd. Takie operacje wykonuje ciotka bohatera, która cierpienia Niemców uznaje za zasłużoną karę. W powieści czytamy:

My na przesiedleniach wyszliśmy gorzej niż Niemcy, chociaż to myśmy wojnę wygrali, a oni przegrali. Gorzej na tym wyszliśmy, chociaż to Szwaby rozpoczęły wojnę i nas napadły $^{26}$.

Niemieckie doświadczenie zatem staje się rodzajem sprawiedliwości historycznej, wątpliwym wyrównywaniem rachunków. Takie zrównanie win jest jedną ze strategii odsuwania od siebie odpowiedzialności za zło, która polega na kompensacji (zestawienie ze sobą krzywd sprawia, że w wyniku operacji matematycznej domniemana wina zostaje anulowana) ${ }^{27}$. Matka bohatera, oskarżana o ukrywanie przed chłopcem prawdy, posuwa się do pewnego uogólnienia, za pomocą którego oddala od siebie poczucie odpowiedzialności i neutralizuje ewentualny dyskomfort:

Może rzeczywiście Niemcy byli po drugiej wojnie światowej wypędzani z naszego kraju, ale tak samo z Polski i z Czechosłowacji; co więcej, prawie ze wszystkich państw, które okupowali. My sami nic nikomu nie zabraliśmy, za decyzją, by nam przydzielić szwabski dom, stała praktycznie cała Europa ${ }^{28}$.

${ }^{23}$ Symptomatyczny jest fakt, że w tym przypadku fikcja literacka ma swe wyraźne umocowanie w rzeczywistości. M. Stojčić, powołując się na badania Janjetovicia, konkluduje, że Niemcy z Wojwodiny w podręcznikach do historii wydawanych w latach 1918-2000 wspominani są tylko w związku z jednym wydarzeniem, tj. kolonizacją i powojenną reformą agrarną. Nie pojawia się w nich natomiast informacja o przymusowych wysiedleniach. Z. Jagnjetović, Nemci Jugoslavije u srpskim udžbenicima 1918-2000 [w:] Prvi i drugi međunarodni seminar Zajednice Nijemaca u Hrvatskoj 2001/2002, red. N. Rittig-Beljak, Zagreb 2002, s. 125-134, za: M. Stojčić, op. cit., s. 26-27.

24 I. Marojević, op. cit., s. 137.

25 M. Czermińska, O dwuznaczności sytuacji ofiary [w:] Kultura po przejściach ..., s. 91.

26 I. Marojević, op. cit., s. 45-46.

27 Zob. A. Assmann, Pięć strategii wypierania ze świadomości, przeł. A. Pełka [w:] Pamięć zbiorowa i kulturowa. Wspótczesna perspektywa niemiecka, red. M. Saryusz-Wolska, Kraków 2009, s. 334.

28 I. Marojević, op. cit., s. 129. 
Ciotka chłopca zaś tak to widzi: „Zaproponowano im nowe majątki i nie słyszałam, żeby im tam było źle. [...] Po prostu opuścili cudzy kraj i przybyli do swojego"29. Zupełnie odmiennie przymusowe przesiedlenia postrzega Sonja Schlösser:

Trafili do Zindelfingen, w tym czasie częściowo zburzonego, ubogiego miasteczka w południowo-zachodnich Niemczech; gdyby nie pomoc Czerwonego Krzyża i niektórych organizacji bliskich Kościołowi, to większość z nich pewnie umarłaby tam z głodu ${ }^{30}$.

Warto zwrócić uwagę na dwukrotne domyślne użycie przez ciotkę bohatera w cytowanym powyżej fragmencie (,zaproponowano im”, „,oni opuścili”) zaimka „oni” na określenie zarówno Niemców, jak i władz komunistycznych (w większości Serbów) - za czym kryje się potrzeba zaznaczenia dystansu i podkreślenia różnicy.

Serbscy osadnicy niezwykle łatwo przyswajają sobie binarny podział, w ramach którego przedstawiciel narodu niemieckiego jest a priori winny. Samych siebie zaś sytuują w pozycji ofiary. Do przesiedlenia zostali bowiem zmuszeni, podczas podróży narażeni byli na różnego rodzaju niedogodności (podróżują w wagonach bez toalety, następnie ciężarówkami i pieszo; wielu z nich od monotonnego hałasu w wagonach wariuje). Poczucie wyobcowania i lęk wynikający z dyslokacji potęgują niechęć, jaką osadników darzą starzy mieszkańcy Vrbasu. Ponadto Serbowie, wykorzystując fakt, że koloniści podczas długiej podróży są głodni, drastycznie podwyższają ceny żywności. Po przybyciu na miejsce zaś nowi mieszkańcy Bački poddawani są upokarzającemu procesowi dezynfekcji - są zmuszeni do kąpieli w publicznym basenie. Jak się później okazuje, wielu z nich nie jest w stanie przywyknąć do panońskiej równiny (liczne samobójstwa) ${ }^{31}$. Jednak te doświadczenia przez kolejne lata będą tłumione, a pamięć o nich zostanie głęboko zdeponowana w osobistych archiwach i zakamuflowana codzienną krzątaniną. Kończące powieść samobójstwo ciotki chłopca, które przypieczętowuje decyzję o jego powrocie do domu (do Perastu), można odczytywać jako spóźnioną, retroaktywną odpowiedź na wielowymiarową traumę przesiedlenia, której kulminacyjnym punktem była kąpiel w miejskim basenie.

Gdy patrzyli, jak my, dziewczęta, się rozbieramy, to niektórzy z nich [...] gwizdali. Strasznie płakałam, jak gwizdali na $\mathrm{mnie}^{32}$

- wspomina Bonja. Doświadczenie symbolicznej przemocy prawdopodobnie nigdy wcześniej nie zostało wypowiedziane, dopiero pojawienie się chłopca, który

29 Ibid., s. 45.

30 Ibid., s. 84.

31 Porównując sytuację Niemców i serbskich osadników w Vrbasie, Bonja wyraża następujący pogląd: „Zostawiliśmy własny kraj i przybyliśmy też do naszego. Ale wydawał nam się obcy”. I. Marojević, op. cit., s. 45 . O chorobowych symptomach wynikających z doświadczenia przesiedlenia interesująco piszą Małgorzata Mikołajczak w tekście Choroba migrantów - literacka epikryza i patogeneza (na przykladzie narracji osadniczej i postosadnieczej) oraz Kinga Sewior w artykule Ciało (post)przesiedleńcze w zbiorowej pracy Białe maski/szare twarze. Ciało, pamięć, performatywność w perspektywie postzależnościowej, red. E. Graczyk, M. Graban-Pomirska, M. Horodecka, M. Żołkoś, Kraków 2015, s. 169-188 i 189-204.

32 I. Marojević, op. cit., s. 47. 
z empatią podchodzi do losu Niemców, wywołuje w ciotce potrzebę opowiedzenia o własnej (ale również zbiorowej) traumie i pozbycia się kamuflażu najsilniejszej osoby w rodzinie, dzięki której wszystko w poniemieckim domu doskonale funkcjonuje.

Powieść Marojevicia jest utworem o dorastaniu, utracie niewinności, która związana jest z poznaniem. Bohater niewinność traci podwójnie: w akcie seksualnym i w momencie zdobycia wiedzy, że dom, w którym mieszka, został skonfiskowany niemieckiej rodzinie, a on należy do narodu, z którego wywodzili się obozowi oprawcy. Chociaż, jak czytamy na kartach książki, on sam nie czuje się odpowiedzialny, to jednak starsza z sióstr kilkakrotnie również jemu przypisuje winę: „Nawet jeśli jesteś dobrze wychowanym chłopcem, to należysz do narodu, który w cztery lata, od 1944 do 1948 roku, wymordował około 60 tysięcy Niemców”33, „Każda dziewczyna, którą napastowaliście w fabryce jedwabiu”34. Paradoksalnie, jakby wbrew doświadczeniom własnego narodu, Sonja odpowiedzialnością obarcza wszystkich przedstawicieli serbskiej nacji.

Kontrdyskurs tworzony przez opresjonowanych, który podważa i problematyzuje dyskurs centrum, najwyraźniej pobrzmiewa w ostatniej rozmowie, jaką chłopiec prowadzi ze starszą z sióstr tuż przed jej wyjazdem z Serbii. Sonia powraca $\mathrm{w}$ niej wspomnieniami do pobytu matki w obozie pracy i do seksualnego wykorzystywania, jakiego doświadczały młode Niemki ze strony zarządców. Hanna Gosk trafnie zauważa, że drastyczne sceny podporządkowywania i upokarzania słabszych (badaczka ma na myśli sceny gwałtu i rekwizycji, które odnajduje w utworach Konwickiego) wpisują się w poetykę double vision, dochodzącą do głosu w sytuacji rozszczelnienia dyskursu dominującego, kiedy to spod jego powierzchni zaczyna wydobywać się wersja nieoficjalna, ukazująca oblicze pogardy dla poddanego i przemocy, którą wymusza się przez posłuch ${ }^{35}$. Warto zaznaczyć, że w przywoływanych przez siostrę Schlösser scenach upokarzania dochodzi do głosu ambiwalentny stosunek Niemek do Serbów. Strach miesza się w nim z poczuciem wyższości i pogardą, czemu daje wyraz Sonja, wykrzykując w stronę bohatera:

Chociaż wszyscy ci strażnicy i ich koledzy, którzy zabawiali się z moją matką, z Paulą Levenstein i kilkoma innymi młodymi Niemkami, chwilowo mieli władzę, to w rzeczywistości byli tym, co zawsze: krwawą chłopską hordą! [...] A one nawet czując ich członki, wciąż pozostawały die Fräulein! ${ }^{36}$

W powieści Marojevicia „centrum nie dysponuje przewagą cywilizacyjno-kulturową, a reprezentuje gołą, fizyczną przemoc"37. Tym większe niezrozumienie otacza matkę Sonji, która w obozie pracy trafia pod opiekę jednego ze strażników, a po opuszczeniu obozu - wiąże się z nim.

33 Ibid., s. 205.

34 Ibid., s. 204.

35 H. Gosk, Opowieści skolonizowanego/kolonizatora. W kręgu studiów postazależnościowych nad literatura XX i XXI wieku, Kraków 2010, s. 152-153.

36 I. Marojević, op. cit., s. 204.

37 Refleksja Hanny Gosk dotyczy relacji polsko-rosyjskich. H. Gosk, op. cit., s. 167. 
Ograniczenia, jakie napotykają przedstawiciele narodu niemieckiego w społeczeństwie serbskim, dotyczą niemożności wyartykułowania własnej traumy (winni nie mają prawa głosu, ich cierpienie nie jest godne opłakania) ${ }^{38}$, naruszenia dotychczasowego, bezpiecznego świata (konfiskaty majątku, przemieszczenia), a także poczucia opresji, wynikającego z późniejszej stygmatyzacji. Dystansowanie się od siebie obu (tj. serbskiej i niemieckiej) grup narodowościowych nie ustaje bowiem nawet wiele lat po wojnie. Wydawać się może, że niemiecka kolektywna wina nigdy nie zostanie odpuszczona i zapomniana. Tak odczytywać można fakt, że jeden z kolegów głównego bohatera (Bokan), który przez pewien czas pozostaje $\mathrm{w}$ młodzieńczym związku miłosnym z młodszą z sióstr, często zwraca się do niej, używając zaimka ,wy” (tj. Niemcy), a siebie włączając w grupowe „my” (Serbowie utożsamiani ze zwycięzcami wojennymi). Herta komentuje to w sposób następujący: Bokan ,uważał, że my musimy bardzo się przed tymi »nimi« korzyć"39. Wzajemne relacje pomiędzy przedstawicielami obu narodów naznaczone są nienawiścią, wrogością, nieufnością bądź, w najlepszym wypadku, poczuciem wyższości wynikającym z wygranej wojny.

Wyznaczenie kolektywnej ofiary automatycznie wiąże się ze wskazaniem zbiorowego winnego, a to z kolei sprawia, że dochodzi również do stłumienia tych wersji przeszłości, które nie wpisują się w oficjalny jej obraz. Potwierdzenie trafności tych uwag znajdujemy w utworze Marojevicia, w którym pokazane zostaje, w jak różnorodne konstelacje na przestrzeni kilku dziesiątków lat wchodzą odrębne, polemicznie wobec siebie usytuowane narracje. Sama powieść ponadto dowodzi, że społeczne ramy pamięci nie są raz na zawsze dane, a wiedza o przeszłości podlega, w zależności od zapotrzebowania chwili, nieustannym fluktuacjom.

Jak to już zostało powiedziane, Igor Marojević w swojej powieści oddaje głos przedstawicielkom społeczności niemieckiej, a jego bohater staje się swego rodzaju medium, poprzez które czytelnik poznaje opowieści dotąd tłumione (osób skrzywdzonych, a więc ofiar). Na to, jak trudna i niejednoznaczna etycznie jest rola przekaziciela cudzego cierpienia, wskazuje Ewa Domańska, która twierdzi, że zajmując taką pozycję, łatwo uwikłać się w tworzenie atrakcyjnego modelu idealnej ofiary, której odbiera się głos i zastępuje go swoim ${ }^{40}$. Odpowiedź na pytanie, czy Marojević zawłaszczył cudzą historię, wymaga bardziej szczegółowych badań i głębszego namysłu. W tym miejscu pragnę jedynie podkreślić, że w utworze wyraźnie pobrzmiewa głos jego twórcy, zaś pewne fragmenty powieści podporządkowane są - moim zdaniem - z góry założonej tezie. Warto w tym kontekście zaznaczyć, że upokorzeniom związanym z wykorzystywaniem seksualnym poddana zostaje niewinna, mająca małe dziecko, piękna Niemka.

38 Zob. J. Butler, op. cit.

39 I. Marojević, op. cit., s. 151.

40 Zob. E. Domańska, O poznawczym uprzywilejowaniu ofiary. (Uwagi metodologiczne) [w:] (Nie)obecność. Pominięcia i przemilczenia..., s. 19-36. 
A Maria była sobie sama winna, że ją posłali do fabryki jedwabiu: gdyby nie była taka młoda i przystojna, to może by jej tam nawet nie zabrali. Miała już trzyletnie dziecko - Sonię, ale dopiero skończyła 20 lat i nie było jeszcze na jej ciele śladów tego, że rodziła ${ }^{41}$.

Pewną tendencyjność, łatwość, z jaką Marojević przypisuje aksjologiczne kwalifikacje, widać szczególnie wtedy, gdy opis Niemki zestawimy z bezczelnym, typowym dla męskich agresorów stwierdzeniem Bonji, która wykrzykuje w stronę swego podopiecznego: „A nawet jeśli nasi naprawdę zgwałcili matkę tej Niemki, to przynajmniej po raz pierwszy poczuła prawdziwych mężczyzn!"42. Brak w tej wypowiedzi cienia współczucia czy empatii. W obu przytoczonych fragmentach wyraźnie słychać męski głos, a więc głos Marojevicia, który przekazuje traumę „Innego”, a jednocześnie odpowiada na nią ze swojego, z góry przyjętego i wyraźnie wyznaczonego, punktu widzenia ${ }^{43}$. Jedyną otwartą osobą w powieści, skłonną naprawdę usłyszeć głos „Innego” (głos indywidualny, któremu nie towarzyszy komunistyczna retoryka), jest szesnastoletni bohater ${ }^{44}$. W świecie powieściowym postać ta jest autonomiczna w tym sensie, że nie została ukształtowana przez zbiorowość. Prymat ma w niej pamięć jednostkowa nad pamięcią zbiorową. Można ponadto przyjąć, że chłopcu - przybywającemu przecież z zewnątrz - łatwiej poznać prawdy do tej pory zakryte, którymi niełatwo się dzielić (myślę tu zarówno o historii rodziny Schlösser, jak i doświadczeniu upokorzenia, jakie przekazuje mu ciotka Bonja, opowiadając o drodze serbskich przesiedleńców i ich pierwszym spotkaniu z nowym miejscem).

Na koniec dodam jedynie, że w moim przekonaniu powieść serbskiego autora nie jest utworem znakomitym, momentami wydaje się tendencyjna, a jej twórca zbyt łatwo szafuje oskarżeniami. Mimo to jest to utwór ważny, podejmujący trudne tematy i próbujący uporać się z tłumioną przez lata traumą mniejszości oraz serbską winą.

Jeszcze raz podkreślić wypada, że opowieść o doświadczeniach naddunajskich Szwabów naruszała ustanowiony po wojnie czarno-biały obraz świata i wówczas mogła stanowić rewolucyjne zagrożenie dla jugosłowiańskiej opowieści fundacyjnej. Wydana w 2011 roku książka Marojevicia pośrednio kwestionuje serbski mit ofiary, od wieków konstytuujący tożsamość tego narodu.

Żałoba, ufundowana na przekonaniu o potrzebie zadośćuczynienia, jak pisze Dominick LaCapra:

to jednoczesne pamiętanie i dystansowanie się wobec przeszłości, czy też jej aktywne zapominanie, a przez to dopuszczenie osądu krytycznego i umożliwienie powrotu do życia,

41 I. Marojević, op. cit., s. 178.

42 Ibid., s. 192.

43 Bachtin w jednej ze swoich wczesnych prac tego rodzaju uprzywilejowaną pozycję, jaką autor może zająć wobec swego bohatera nazywa pozycją zwieńczającą. Zob. M. Bachtin, Autor i bohater w działalności estetycznej [w:] idem, Estetyka twórczości słownej, przeł. D. Ulicka, oprac., przekł. i wstęp E. Czaplejewicz, Warszawa 1986, s. 35-275.

44 Na podobną strategię, w której medium bez uprzedzeń rejestrującym opowieść „Innego” jest przedstawiciel pokolenia dopiero wchodzącego w dorosłość, wskazuje A. Gawarecka w tekście Dialog i milczenie w czeskiej prozie poświęconej tematyce wysiedlania Niemców (A. Gawarecka, op. cit., s. 195-215). 
szczególnie życia społecznego i obywatelskiego z uwzględnieniem odpowiedzialności, wymogów i norm związanych z szacunkiem dla innych ${ }^{45}$.

Powieść Marojevicia można zatem postrzegać jako próbę oddania sprawiedliwości. Autor, mający skłonność do literackiej prowokacji i obnażania wstydliwych momentów z przeszłości swego narodu ${ }^{46}$, podjął wysiłek wskazania na te opowieści, które domagają się scalenia z wersją oficjalną, by w ten sposób spróbować zbliżyć się do prawdy wielogłosowej narracji historycznej.

\section{Bibliografia}

Assmann A., Pięć strategii wypierania ze świadomości, przeł. A. Pełka [w:] Pamięć zbiorowa i kulturowa. Współczesna perspektywa niemiecka, red. M. Saryusz-Wolska, Kraków 2009.

Bachtin M., Autor i bohater w działalności estetycznej [w:] idem, Estetyka twórczości słownej, przeł. D. Ulicka, oprac., przekł. i wstęp E. Czaplejewicz, Warszawa 1986.

Butler J., Ramy wojny. Kiedy życie godne jest opłakiwania?, przeł. A. Czarnecka, Warszawa 2011.

Carrol D., Reguły gry, przeł. G. Dziamski [w:] Postmodernizm w perspektywie filozoficzno-kulturowej, red. A. Zeidler-Janiszewska, Warszawa 1991.

Czapliński P., Język niezależności. Jak jest artykułowana w literaturze niepodległość odzyskana przez Polskę w roku 1989? [w:] Kultura po przejściach, osoby z przeszłością. Polski dyskurs postzależnościowy - konteksty i perspektywy badawcze, red. R. Nycz, Kraków 2011.

Czermińska M., O dwuznaczności sytuacji ofiary [w:] Kultura po przejściach, osoby z przeszłościa. Polski dyskurs postzależnościowy - konteksty i perspektywy badawcze, red. R. Nycz, Kraków 2011.

Domańska E., O poznawczym uprzywilejowaniu ofiary. (Uwagi metodologiczne) [w:] (Nie)obecność. Pominięcia i przemilczenia w narracjach XX wieku, red. H. Gosk, B. Karwowska, Warszawa 2008.

Dunđerin A., Budalaština (o novom romanu I. Marojevicia), „Pečat”, 22.09.2011, http://www.pecat.co.rs/2011/09/budalastina-o-novom-romanu-i-marojevica/ (dostęp: 22.08.2016).

45 D. LaCapra, Trauma, nieobecność, utrata, przeł. K. Bojarska [w:] Antologia studiów nad trauma, red. T. Łysak, Kraków 2015, s. 90.

46 Przez niektórych przedstawicieli „narodowo zorientowanej” krytyki literackiej serbski autor oskarżany jest o propagowanie przekonania, jakoby serbski naród wyposażony był w gen ludobójstwa (genocidni gen srpskog naroda), oraz o zakłamywanie historii (to sformułowanie odnosi się do innej powieści Marojevicia, zatytułowanej Šnit z 2007 r., której akcja została umieszczona w okupowanym przez Niemców Belgradzie i włączonym do NDH Zemunie). Zob. A. Dunđerin, Budalaština (o novom romanu I. Marojevicia), „Pečat”, 22.09.2011, http://www.pecat.co.rs/2011/09/budalastina-o-novom-romanu-i-marojevica/ (dostęp: 22.08.2016). Obie powieści (tj. Majčina ruka i Šnit) wraz z opublikowanym w 2004 r. utworem Žega wchodzą w skład zaplanowanego przez autora cyklu Etnofikcija, obejmującego tematykę związaną z najważniejszymi XX-wiecznymi wydarzeniami, w których brali udział Serbowie. 
Dyras M., Rekonstrukcje tożsamości „naddunajskich Szwabów” wobec wielojęzyczności kulturowej [w:] Konstrukcje i destrukcje tożsamości, t. 2: Tożsamość wobec wielojęzyczności, red. E. Golachowska, A. Zielińska, Warszawa 2012.

Gawarecka A., Dialog i milczenie w czeskiej prozie poświęconej tematyce wysiedlania Niemców [w:] Przemilczenia w relacjach międzykulturowych, red. J. Goszczyńska, G. Szwat-Gyłybowa, Warszawa 2008.

Gosk H., Opowieści skolonizowanego/kolonizatora. W kręgu studiów postazależnościowych nad literatura XX $i$ XXI wieku, Kraków 2010.

Horozović N., Istraživanje: tišina od 60 godina, http://nenasilje.org/2010/istrazivanje-tisina-od-60-godina/ (dostęp: 29.07.2016).

Janjetović Z., Srbi i Nemci u Vojvodini: negativna iskustva zajedničkog života, http:// www.drustvosns.org/nemacka\%20manjina/janjetovic/Z.\%20Janjetovic, \%20 Srbi\%20i\%20Nemci\%20u\%20Vojvodini,\%20negativna\%20iskustva\%20zajednickog\%20zivota.pdf (dostęp: 24.05.2016).

Jedan svet na Dunavu - Razgovori i komentari, red. N. Stefanović, Beograd 2007.

Kołodziejczyk D., Odzyskiwanie miejsca: realizm magiczny w powieści postkolonialnej i polskiej powieści lat dziewięćdziesiatych XX wieku [w:] (Nie)obecność. Pominięcia i przemilczenia $w$ narracjach XX wieku, red. H. Gosk, B. Karwowska, Warszawa 2008.

Kuljić T., Prevladanje prošlosti. Uzroci i pravci promene slike istorije krajem XX veka, Beograd 2002.

LaCapra D., Trauma, nieobecność, utrata, przeł. K. Bojarska [w:] Antologia studiów nad trauma, red. T. Łysak, Kraków 2015.

Marojević I., Majčina ruka, Beograd 2011.

Mikołajczak M., Choroba migrantów - literacka epikryza i patogeneza (na przykładzie narracji osadniczej i postosadnieczej) [w:] Białe maski/szare twarze. Ciało, pamięć, performatywność w perspektywie postzależnościowej, red. E. Graczyk, M. Graban-Pomirska, M. Horodecka, M. Żołkoś, Kraków 2015.

Petrović Todosijević S., Na putu. Repatrijacija dece pripadnika nemačke nacionalne manjine u Jugoslaviji posle Drugog svetskog rata (1948-1956), „Tokovi istorije” 2012, nr 3.

Sewior K., Ciało (post)przesiedleńcze w zbiorowej pracy Białe maski/szare twarze [w:] Ciało, pamięć, performatywność w perspektywie postzależnościowej, red. E. Graczyk, M. Graban-Pomirska, M. Horodecka, M. Żołkoś, Kraków 2015.

Spivak G.Ch., Czy podporzadkowani inni moga przemówić, thum. E. Majewska, „Krytyka Polityczna” 2011, nr 24-25.

Stojčić M., Recepcija stradanja Nemaca i Nemica iz istočnoevropskih oblasti nakon drugog svetskog rata u Nemačkoj i Podunavskih Nemaca/ica u Srbiji/Jugoslaviji, s. 26-33 (w druku). 